\title{
INTERIORITY, TRASLACIÓN, AND THE DEVOTION TO THE BLACK NAZARENE
}

\author{
Mark Joseph T. Calano \\ Ateneo de Manila University \\ mcalano@ateneo.edu
}

\begin{abstract}
The play in the performance of panatà to the Black Nazarene in Quiapo, Manila, demonstrates an authentic religiosity that is manifested in materiality, and a modernity that is indigenous. The paper operates within the framework of a panatà (devotion) as: (1) a personal (even inherited) secret vow; (2) that is performed publicly; and (3) is directed towards touching and being touched by God. The first part discusses the dynamics of how petition and thanksgiving are interior movements that reflect útang-na-loób (debt of gratitude) as dasál (prayer). But this movement, although essentially personal and secret, can only be expressed in the communal and public performance of the yearly procession (traslación). The second part discusses this public and communal "translation" of the Black Nazarene as a construction of a relationship with the sacred that is embodied and embedded. And the third part investigates the encounter (hierophany) through the appropriation of the poón (icon) within the dynamics between hirap (difficulty, suffering, poverty) and ginhawa (rest, relief, ease) in the kalye (streets) of Manila.
\end{abstract}

\section{Keywords}

Panatà, Devotion, debt-of-gratitude, informality, modern religiosity, Hirap-Ginhawa,

\section{About the Author}

Mark Joseph T. Calano is an Associate Professor of Philosophy, Coordinator for Research and Creative Work of the School of Humanities, and Faculty Campus Minister of the Loyola Schools, Ateneo de Manila University. He teaches Philosophy of Religion and Thomas Aquinas. For the past years, his research interest has been focused on the performance of devotion to the Black Nazarene in Quiapo, Manila; his most recent publication on the devotion can be found in Budhi: A Journal of Ideas and Culture (vol. 22, no. 2, 2018). 


\section{QUESTION AND WAY OF PROCEEDING}

The devotion to the Black Nazarene in Quiapo, Manila, remains the most attended, most publicized, and most misunderstood of all religious performances in the Philippines; many journalists refer to it as "a masterpiece in madness," "a canvas of immeasurable chaos," "the most rambunctious and unruly observance on the local liturgical calendar," or "the Nazarene's Nightmare" (Trinidad; JimenezDavid; Doyo). Over the past years, there has been an exponential growth in the number of mamámasán ${ }^{1}$ (devotees who carry and pull the carroza of the Black Nazarene along the procession route) and other devotees, who participate in the annual procession (traslación) (Guidaben). As such, it continues to interest local and international media (Brown \& Firefly; Uy; Genova), sociologists and anthropologists, and philosophers of religion (Tremlett; Cornelio; Calano). But the popularity of the devotion is not without its critics. Other than the journalists already mentioned above, Chan (2005) describes, for example, the devotion as unsophisticated, superstitious, emotional, individualistic, reactionary, and even anti-liturgical; others do not look at the devotion but its consequence in terms of damaged properties, physical injuries, and lost lives (Pagulong; Philippine News Agency; Hegina and Lozada). Perhaps there is a need to contextualize the devotion to the Black Nazarene, and to go beyond the many frameworks and different -isms that seem to simplify the complexity of this endemic religious and modern phenomenon (Pace; Parker; Sapitula). Bautista (2011) argues that this phenomenological epoché or suspension, respects "the agency of its practitioners."

This paper investigates the dynamics of panatà in the performance of the devotion to the Black Nazarene; in doing so, the paper takes a phenomenological stance that triangulates ethnographic data with the use of participant-observation, interviews, and document analysis. The structure of the paper revolves around an understanding of panatà as a private vow (even inherited), performed publicly and communally, in the hope of encountering God in the kalye (streets) of Manila. It argues that what is often dismissed as a split-level Christianity (Bulatao) constitutes a play that is interiorly motivated and, at the same time, materially, communally, and contextually grounded (cf. McGuire and Ammerman). It is a demonstration of how modern Filipinos appropriate Christianity "to suit ways of local thinking, believing, and doing things" (Jocano), and have brought it to their everyday experiences of hirap (difficulty, suffering, poverty) and ginhawa (rest, relief, ease). 


\section{ÚTANG-NA-LOÓB AS DASÁL}

The devotion to the Black Nazarene in Quiapo cannot be understood separately from the life expressions of Filipinos or apart from their expressions of pananampalataya $^{2}$ (Macdonald). But at the core of this religious devotion and performance is the people's panatà. ${ }^{3}$ People from different socio-economic status, occupation, educational levels, ages, and even religion fill the Minor Basilica of the Black Nazarene in Quiapo every Friday and the streets of Manila during the traslación every January 9; the difference can be understood within an economy of grace, and in the distinction between ordinary and religious space and time (Eliade). More importantly, the variety of people presupposes a multiplicity of personal expressions and religious experiences. There is always a plurality of voices and expressions (heteroglossia; Bakhtin), a multiverse of rationalities in Quiapo (Rodriguez). Only an observer in the church can identify external traces and manifestations of an internal promise-a panatà, such as but not limited to, praying on their knees, walking barefoot during processions, kissing statues and wiping them with towels, offering sampaguita garlands, using rosary beads, receiving the sacraments, the waving of towels and handkerchiefs, and the offering of candles. Gestures of faith differ from one another. Others are communal and "noisy," while some are silent and solitary. Some just gaze at the poón on the altar, while others carry a replica on their shoulders. The panatà is essentially a personal promise made by the devotee. It is made in secret and, as such, is known only to the person making it. Since each devotee has his or her own way of expressing his or her own panatà, it is difficult to determine the content of the panatà; this devotion is hinged on a sense of modern interiority (cf. Taylor). The panatà is like a "private religion" (Murphy and Hogan) because its content is always secret, yet the expression is not: it is always communal and public.

Since it is a personal and a secret promise, the panatà involves the dynamics of the loób (Mercado; Ileto; Alejo). The loób is the Filipino metonymy and the epiphany of the person. This means that the person making the panatà commits his or her loób as a response to a petition, a form of sacrifice and penance, or as an act of thanksgiving. Because the loób is involved, the promise cannot simply be reduced to a transactional act (Zialcita); that there is an asking and a receiving implies a risking of the loób that is beyond calculation. It cannot be computed nor paid. Because the panatà hinges on an asking or giving of a favor, it entails a debt of gratitude that can never be paid-an útang-na-loób. The útang-na-loób destines (even binds) the person (and his or her entire family) to a life of panatá; in this case it becomes clear why it is inherited. As explained above, panatá, committed to the útang-na-loób, is always a secret (Derrida and Ferarris); it is so tied to what is fundamentally important to the person that it determines both what is worth living and dying for. Just as the loób, the authentic self, cannot be easily unpacked, so one

Kritika Kultura 35 (2020): 7-020

(C) Ateneo de Manila University

<http://journals.ateneo.edu/ojs/kk/> 
cannot simply speak of his or her panatá. It is forbidden to do so because its bisa (potency) is lost at its very articulation (De La Paz); for to speak of one's panatà is to make vulnerable one's most authentic self and expose one's fundamental commitments. Thus, the panatà is best left unarticulated. The secrecy of the panatá and its constitution as útang-na-loób, then, mobilizes and sustains the devotion to the Black Nazarene. Since the panatá is an interior movement, it is not easily discernible. It is always customized, differentiated, and individualized; in a way, it is attached to an understanding of self-realization or fulfillment (Taylor). Because it is one's very self that is at stake, a panatá cannot simply be reduced to a mere commitment with others. The object of the panatá cannot simply be others; it entails more-the totally Other. It is something to take to heart for it entails a relationship with God.

It is not accidental, according to De Mesa and Wostyn, that embodying the lowland Filipino faith experience necessitates the use of loób and, therefore, of kagandahang-loób. Whereas loób is already defined above, kagandahang-loób refers to everything that is good in the person expressed in the totality of his or her life and interrelationship. Kagandahang-loób can only come from the loób; in constrast, kasamaan ng loób can only be grounded on other prudential considerations. De Mesa and Wostyn argue that kagandahang-loób and loób embody "the very depths of Godhood-designated as 'beautiful' or eminently good-which we experience because loób is the core of one's personhood" (127). In short, we have útang-naloób because God gives that which is in His very self (kagandahang-loób). In the dynamics between loób and kagandahang-loób, panatá emerges naturally as a response in the life of faith. It seems that there is nothing more binding than this process of interiorizing for this interiorizing is a reminder of God's benevolence that permeates the very depths of one's self. However, because the útang-na-loób is never satisfied, the panatá is never separate from the ordeal and the interiorizing never stops. It is, in a way, insatiable and, as such, is infinite in depth; this justifies why panatá is inherited and passed on (and better understood in the context of the Filipino value of útang-na-loób).

\section{TRASLACIÓN AS COMMUNAL EXPRESSION}

Since útang-na-loób is a relational concept, so is panatá. For the panatá cannot remain simply as a personal promise made in secret, its public and communal performance completes it. In the case of the devotion to the Black Nazarene, devotees and mamámasán, each with his or her own panatá, participate, observe, and undergo the traslación. It is safe to claim that the panatá is "translated," "actualized," and "materialized" in the traslación. Panatá is "translated" because 


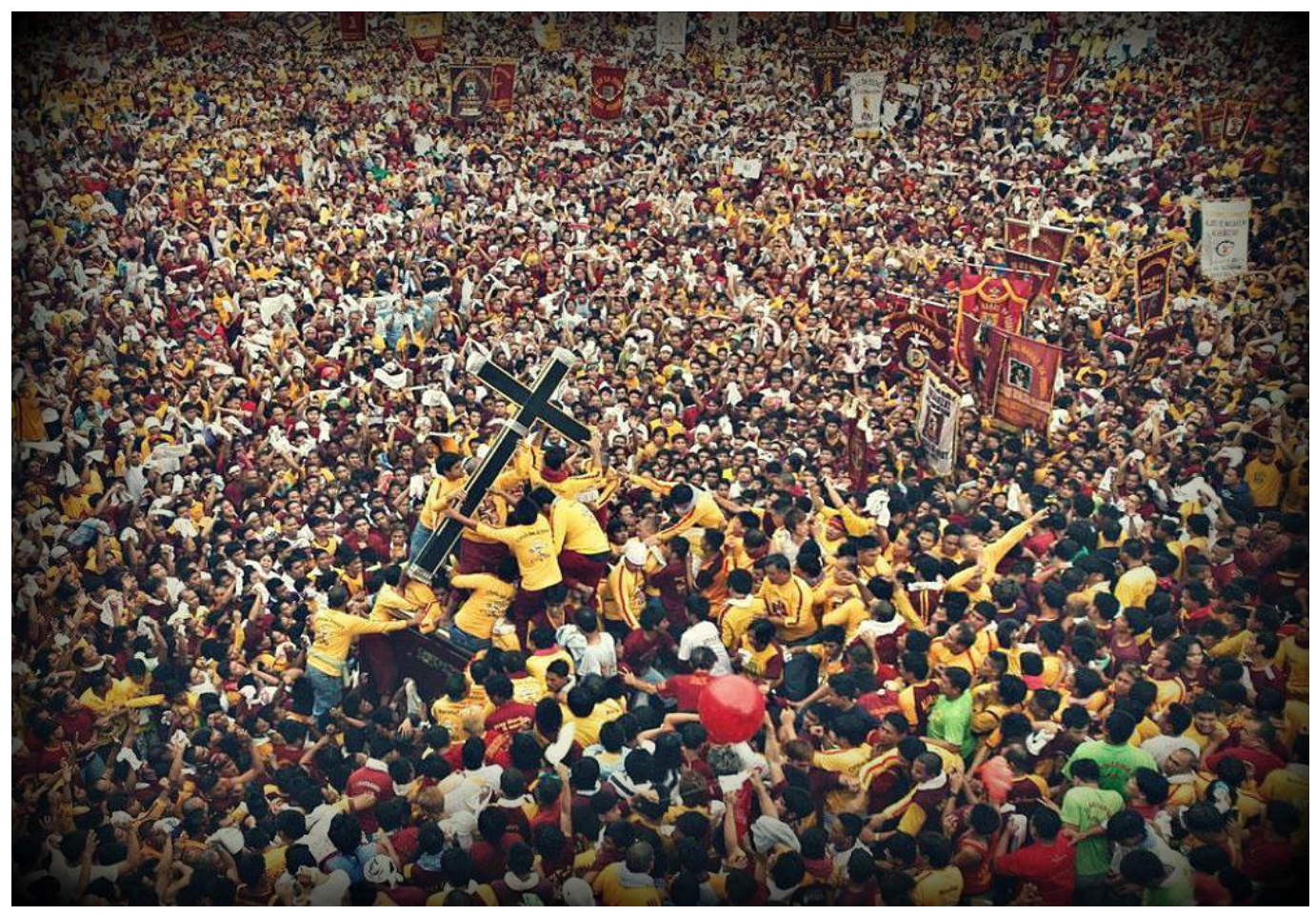

Fig. 1. The commencement of the 2014 Traslación.

(Personal photo of Pong Dizon, used with permission.)

the procession allows others to explicitly see the devotees' internal promises; "actualized" because participation in the traslacion is the very expression of this devotion. Lastly, panatá is materialized because the procession is the concrete manifestation of this devotion.

Described annually as a pandemonium, the most popular is the January 9 procession or the traslación; it is recommended to watch videos of the procession in the Internet. But there are other processions such as the Domingo de Lazaro, where the Nazarene is brought outside to visit the fourteen stations of the Via Crucis, the Good Friday Procession, and the January 1 procession to mark the beginning of the novena which ends on January 9. For some reason, within religious sensibility, place, and time, the January 9 procession or the traslación seems to be the most appropriate venue and moment to fulfill or to perform one's panatá; this appropriateness can be attributed to the temporary suspension of space and time. "Space" because the kalye becomes a place not only to encounter the other, but also God; "time" because January 9 is understood as a sacred moment-a moment of grace. 
Local authorities such as the Philippine National Police and the City Government of Manila loosely estimate about 10 to 15 million $^{4}$ devotees in the 2016 traslación, and more devotees in total attending the daily novena masses. During the traslación, devotees and mamámasán wear a distinctively maroon or yellow shirt, without watches or jewelries, and with buttonless loose pants; together, they walk the streets of Manila, usually barefoot, in a procession that can last from 18 to 23 hours. Traditionally, only men are permitted to be a mamámasán, but in recent years, a growing number of females and children participate at their own risk. In pulling the ropes or carrying the ándas (carriage or bier), there is a preference for doing so on the right shoulder (kanang balikat) because the poón (icon or also, image) of the Black Nazarene bears the cross on his right side. In this sense, the actualization of panatà entails not only the holding and pulling the rope of the ándas and touching the poón, but the imitation of the poón. However, to touch the rope of the ándas and, more so, to touch the poón, requires both courage or guts and a good sense of rhythm. There is a need to comply with a certain cadence, movement, and rhythm amidst thousands of competing mamámasán fulfilling their panatà-a requirement that takes years to practice. The fulfillment of the panatà comes after every performance of the traslación, that is, after surviving and persevering the severe physical test and succeeding in touching the ropes or even the poón for the Nazareno's sake. Although deeply personal, the devotion to the Black Nazarene is also very communal (cf. Giddens). Persons with panatà to the Black Nazarene in different locales gather together to form balangays or faith groups. There are no distinctions between the balangays, but each group carries a distinguishable marker. As a testimony of their commitment and thanksgiving for favors requested and given, these balangays carry Roman-style maroon or yellow banners, called istandartes, with the face of the Señor (Black Nazarene) as well as the group's identity and place of origin. The variety of istandartes from all over the country is a sign of the balangay's individual yet shared panatà.

Aside from the balangays, a confraternity-the Hijos del Nazareno-plays an important role in the traslación; they constitute the honor guards tasked to protect the poón and facilitate the performance of the procession. The hijos take different roles such as the mamámasán (those who carry the ándas [carriage] of the poón), anga mangangawil (those who parry electric wires and others using the kawil [hooks]), and the mamamalakaya (those who catch towels and persons). Hijos help those who have a panatà to briefly touch the poón, or they touch the towels and handkerchiefs tossed at them onto parts of the poón. In this sense, there is no distinction among CEOs, politicians, priests, lawyers, educators, laborers, and farmers. Judges pull ropes with criminals, educators hoist up students, and CEOs allow themselves to be stepped on by fellow devotees just to perform their panatà. Differences are thus momentarily dissolved in an experience of communitas (Turner and Turner). The personal and communal aspects of panatà demonstrate how this 
practice is always embodied, but to be embodied necessitates understanding how people's panatà are also moved by the traslación. Quite undeniably, the movement in the poón's physical location, by the pulling and pushing of the ropes attached to the ándas, also mobilizes the loób of the mamámasán and devotees (Bautista). Hence, to be embedded (Giddens) includes the entire sensorium that is created by the density of devotees touching the poón, holding the rope of the ándas, praying audibly or inaudibly, singing, walking on their knees, and participating in the traslación along the streets of Manila. This "religious" experience is composed of the sights, scents, and sounds that create the "mood" which transcends (and suspends) the ordinary (cf. Hervieu-Leger). Giddens refers to this situation of modernity as phantasmagoric.

The panatá reinforces this "pooling of faith" as well as the identification and oneness with the poón and with fellow devotees. But the panatá and the traslación revolve around and are centered on the poón. The materiality of the panatá is directed towards the image of the Black Nazarene, a life-sized wooden poón of Jesus on the way to crucifixion. It is dressed with a maroon velvet robe with a collar and sleeves accented by white ruffs. The head is crowned with thorns and with three rays called potensiyas (from the Spanish potencia, which means power). The poón is barefoot and genuflects on the left knee, as if struggling to get up. The right hand is raised to support the big cross on his right shoulder, while his other hand is free. Around the waist is a gold-plated metal belt with the embossed word "NAZARENO," and looped around the neck and held by its left hand is a golden chain and ball, which represents the scourging. The poón is of dark wood, made even darker through years of wiping it with balsam oil and perfume. The poón is referred to as Nuestro Padre Jesus Nazareno (NPJN)-loosely translated as Our Father Jesus of Nazareth-even if $i t$ is a representation of Jesus, who is the Son and the second person of the Holy Trinity in the Roman Catholic Faith. Orthodox or not, the poón of the Black Nazarene facilitates hierophany, that "irruption of the sacred that results in detaching a territory from the surrounding cosmic milieu and making it qualitatively different" (Eliade).

Materiality also presupposes multiplicity. There is no one poón of the Black Nazarene; there are always already many images and replicas of the poón. Before World War II, there were two Black Nazarene images - the first was in the church of Saint John the Baptist (Quiapo) and the second was in the church of San Nicolas de Tolentino (Recoletos). Unfortunately, there are no records stating what happened to the poón of the Black Nazarene de Recoletos after the war. Currently, there are also two images of the original Black Nazarene in the parish of Saint John the Baptist: (1) the one on the high altar and (2) the vicario (the processional image). The head of the original Black Nazarene is the one on the high altar of the basilica, but its body is made of Philippine molave wood. The vicario, on the other hand, 
retains the original torso, but its head is already of batikuling wood. But aside from the original poón on the high altar and the vicario, the basilica also possesses three replicas of the image visiting the different Roman Catholic dioceses in the country, which are called callejeros. Aside from these images that are housed in the basilica itself, there are hundreds of life-sized and miniature replicas of the Black Nazarene all over the country and they are blessed and processioned every January 8. These replicas also extend the narratives and miracles (himala) attributed to the poón by participation and by extension, and they are worth considering and investigating.

For the mamámasán and devotees, the mere proximity of these "replicas" to the "original" poón is enough to imbue them with bisa (potency) and blessing (Mojares), which they can bring home to their everyday lives. The panatá of devotees and the materiality of the poón help make sense of the indigenous understanding of the salvation that the Black Nazarene brings in the people's everyday struggle with hirap (poverty, difficulty, suffering) and their desire and longing for ginhawa (ease, relief, rest); Yet CEO or vendor are not foreign to all sorts of hirap and to aspirations of ginhawa as well. For the mamámasán and devotees, in the face of all these hirap, the Black Nazarene is the source of ginhawa. Ginhawa is the realistic appraisal of life; it does not assume that hirap is eliminated or vanquished (De Mesa and Wostyn). Ginhawa blurs the distinction between the material and psychological needs and spiritual welfare; it is a welcome relief regardless of whether it is mundane or sacred. While the play of hirap and ginhawa can develop a fatalistic attitude that undermines and obscures human responsibility and that may contribute to the inhuman situations and criminal conditions in Quiapo and Manila, this is a matter of grounding actions in a magandang (versus a masamang) loób. Any ginhawa, as a consequence of the performance of the devotion, is always interpreted in relation to the devotees' panatá and operates within this sense of contentment. But this aspect of the devotion is undergoing change as the mamámasán and devotees judiciously take control of the expression of their selves and communal authenticity (Cornelio).

\section{QUIAPO AS IMAGO MUNDI}

The increasing informality of the devotion in Quiapo is an adaptation to the dynamics of hirap and ginhawa that is personally and communally constituted in space. Since barong-barong (a makeshift dwelling such as a hut or shanty) of Quiapo represents the slums of Manila and the informality that is our culture (Calano), it cannot be argued that hirap is identified simply by the cluster of dilapidated structures inhabited by those who are materially less privileged. Hirap is more complicated than that. It is a lifestyle-Philippine society in a microcosm. Living in hirap cannot simply be contrasted with the gated communities of 
Manila and its inhabitants. Hirap is its own social organization, sets of values, and normative behavior. It cannot simply be reduced to the congestion of the city, or to the consequence of modernity. Hirap is a process of adaptation in itself; it is the way Filipinos effectively use their environment to survive life's given difficulties. Undeniably, hirap is as much a part of the metropolitan city as is its adaptation to it. This adaptation and survival in the face of everyday difficulties and struggles is only made possible because of ginhawa.

Ginhawa constitutes the strategies of coping in the everyday experience of hirap. It is composed of that pragmatism that makes Filipinos more critical, calculated, and attuned to the changing conditions and opportunities that occur in their lifetime. It is interesting to know, but it is beyond the scope of this paper, how given the conditions with which they are in, the devotees and mamámasán, with the meager skills they possess, are able to survive the pressures of urban life. While Filipinos display tremendous flexibility in their values, attitudes, and behaviors, the understanding that the Black Nazarene is a source of ginhawa here and now remains a source of resiliency for the millions of mamámasán and devotees to the Black Nazarene. In the face of real (more than imagined) hirap in Quiapo and in Manila, the devotion to the Black Nazarene is a symbol of hope and a source of authentic ginhawa. Ginhawa plays an important role in the adaptations the mamámasán and devotees use to deal with the pressures of hirap. In this sense, the dynamics of hirap and ginhawa, and the devotion to the Black Nazarene, constitute a way of adapting that Filipinos develop as individuals and share as a group to make life worthwhile and meaningful within the context of existing local conditions of the metropolis.

Ginhawa is an indigenous soteriological concept that can only be brought about by kagandahang-loób. In this sense, the mamámasán and devotees understand the Black Nazarene as pawang kagandahang-loób (perfection of goodwill) because His words and deeds bring people out of hirap into ginhawa. "Only someone who is consistently and persistently intent on bringing about ginhawa for people, can have a loób which is truly maganda" (De Mesa and Wostyn, 310). This explains why in moments of hirap, the mamámasán and devotees go to the Black Nazarene to ask for ginhawa; but in moments of ginhawa, they go back to the Black Nazarene as thanksgiving for His kagandahang-loób. The dynamics of hirap and ginhawa are too personal; they only make sense in relation to the panatá and its public and communal performance. These dynamics can only be understood in the context of panatá as utang na loób-or endless gratitude and return.

During the traslación, panatá, as public and communal, is performed in Manila's kalye (streets). The kalye is the hub of all social affairs (Jocano). It is where the mamámasán and devotees from all walks of life socialize, exchange views, 
meet acquaintances, and express devotion. This explains the heterogeneity of the traslación and its appeal to the masses; the density of those attending it is just unimaginable. The kalye is a source of ginhawa to those escaping boredom at home or experiencing domestic problems; as argued above, ginhawa is only possible in the context of the panatá. It is also a source of ginhawa to those who do business. It is the place for many kinds of information; in short, its informality provides diverse Filipinos with opportunities to know each other better. It is likewise the place of encounter with the Black Nazarene. By encountering the Black Nazarene of ginhawa in the kalye, the streets are made more significant to the people's lifeways. Because the kalye is the yardstick for individual behavior, the communal performance of the panatá is enough to measure and mores (English translation of mores) of devotion and commitment. More than that, the traslación also makes possible alliances and affective links between the different communities, groups, and balangays who share the same devotion to the one Black Nazarene. In Quiapo and in the kalye of Manila, nothing separates the religious from the profane; there is no limit, no boundary, and no frontier that separates, distinguishes, and opposes the two worlds (Calano). The kalye serves as that place where these two worlds communicate and merge. F. Landa Jocano (46) explains the significance of the kalye to slums:

Sociologically, therefore, the street may be viewed as an indicator of social phenomena in the community, a social barometer through which events are learned (by word of mouth) or predicted. When the street, for example, is filled with voices of children and songs of teenagers, the entire neighborhood is awake and in a happy mood. When suddenly it is occupied by people who strain their necks out toward one direction, something unusual is happening in the neighborhood. When the streets are deserted, a dangerous event, like a gang war, is likely to take place any moment or is already taking place elsewhere in the neighborhood.

That the mamámasán and devotees attending the traslación increase in number every year indicates the commitment of the many to their panatà and their encounter with the kagandahang-loób of the Black Nazarene in the face of evergrowing and changing hirap as well as their desire and longing for ginhawa at the heart of Manila.

\section{LOOKING BACK AND FORWARD}

The devotion to the Black Nazarene in Quiapo, Manila, demonstrates an authentic religiosity grounded in panatà. This paper articulates the framework of panatà: (1) as a personal (even inherited) secret vow; (2) that is performed communally and 
publicly, and (3) that is directed towards touching and being touched (haplos) by God understood as ginhawa. But the complexity of the panatà can be understood as rooted and grounded in the Filipino loób, and is tied to one's authentic self. As such, panatà is tied to útang-na-loób (debt of gratitude) that flows out of the person as is thereby shared, even inherited. For mamámasáns and devotees, the perfect time and place for the performance of the individual and shared panatà is during the communal and public performance of the yearly procession (traslación). ${ }^{5}$ In the procession, an encounter (hierophany) takes place through the mediation of the poón (icon) and this meeting in the kalye (streets) of Manila can be understood in a greater narrative of the temporary overcoming the suspension of hirap and the (fore)taste of the ginhawa-to-come. 


\section{Notes}

1. Mamámasán is the endemic term that devotees of Quiapo refer to themselves. Literally referring to the task of carrying (pasan) or pulling the two ropes attached to the image of the Black Nazarene during the traslación. But I am using the words devotees and mamamasan to create a distinction between those who participate in the traslacion passively by just being there and watching (devotees) and those actively touching the ropes of the andas or climbing the andas.

2. Pananampalataya is literally translated as faith. Etymologically, it comes from two Filipino words, pananam and palataya. Pananam refers to the act of tasting, whereas palataya is a term used to refer to gambling. Thus, etymologically, pananampalataya means a taste of what it is to gamble (Miranda 1987, 17-20).

3. In three of thirty-five interview scripts, Rhochie Matienzo (2015) captures the interiority that comes with the panatá. He speaks of Glaiza, a 28-year-old common-law wife from San Pedro Laguna, who collapsed during her first salang (the attempt to touch the image or its garment), but tried again and touched the andas (which is also the carroza) to ask for a child. She said: "Mahirap ipaliwanag ang sarap na nararamdaman, iba ang emosyon... kahit pa nga hinimatay ako kanina sa dami ng tao at hindi na ko nakahinga... Sa loob ko, meron nagtutulak sa akin kahit' 'yung katawan ko pagod na pagod na, sa loob ko may nagsasabi na dapat ko gawin ito." [It is difficult to explain the pleasure that I feel; it is different... Even if I fainted, due to the density of people and due to my inability to breath... in my heart, something is telling me that I should do it. Even if am already so tired, there is a voice that tells me, I should do it (translation and emphasis are mine).] The second interview is from Tatay Boy, who is the president of the Hijos. He speaks of his experience of the Black Nazarene in this way: "Para sa "kin, walang himala pero ang mga imposibleng mangyari, possibleng mangyari sa kalooban mo... walang katiyakan... sa lahat ng pangyayare sa buhay... sa paniniwala mo at sa paniniwala ng ibang tao, maaaring magkakaiba, pero isa lang ang pupuntahan, pananampalataya." [For me, there are no external miracles. But the impossible things happen in the heart... There is no certainty... in the things that happen in one's life... In your belief and so with other people, there can be differences. But there is only one destination-faith (translation and emphasis are mine). ] The third interview is that of Imon, the Balangay head of Antigong Mamamasan, who is responsible for the passing of the koda (methods and jargon) to neophyte devotees. On January 9, 2015, Imon was one of those who brought his fellow Hijos and devotee Renato Guiron (44 y/o) to the hospital. Guiron was declared dead on arrival from cardiac arrest during the first hours of the traslación. "Sa akin personal... talagang mas lalong magtutuloy-tuloy 'yan... Kung anuman ang mangyare ay kailangan nating tanggapin. 'Yung nangyari kay kapatid na Renato, kasama yan sa panata niya. Kasama 'yan sa panata ng bawat mamamasan. Hindi iyan dahilan upang itigil ang panata mo... kasama iyon sa kaganapan ng iyong pamamanata." [Personally... I think the devotion will continue.... What happened to our brother Renato is part of his panatá.

Kritika Kultura 35 (2020): 16-020

(C) Ateneo de Manila University

<http://journals.ateneo.edu/ojs/kk/> 
It is part of every mamamasan's panatá. Death is not enough to stop one's panatá... it is part of the perfection of your panatá (translation mine).]

4. Projected number of 10 to 15 million devotees from "Traslacion preps: Security to draw lessons from Papal visit, APEC summit," CNN Philippines, January 5, 2016: https://cnnphilippines.com/news/2016/01/05/feast-of-the-black-nazarene-traslacionpreparations-preps-security-papal-visit-apec-summit.html.

5. The ethic of panatá is the topic of a forthcoming paper.

Kritika Kultura 35 (2020): 17-020

(c) Ateneo de Manila University

<http://journals.ateneo.edu/ojs/kk/> 


\section{Works Cited}

Alejo, Albert. Tao pô! Tulôy! Isang Landas ng Pag-unawa sa Loob ng Tao. Ateneo de Manila UP, 1990.

Ammerman, Nancy. "Introduction: Observing Religious Modern Lives." Everyday Religion: Observing Modern Religious Lives, edited by Nancy Ammerman, Oxford UP, 2007, pp. 3-18.

Bakhtin, Mikhail. "Discourse in the Novel." Dialogic Imagination, edited by Michael Holquist, U of Texas P, 1981, pp. 259-422.

Bautista, Julius. "Preface: Motion, Devotion, and Materiality in Southeast Asia." The Spirit of Things, edited by Julius Bautista, Southeast Asia Program Publications, Cornell UP, 2012.

--. Figuring Catholicism: An Ethnography of the Santo Niño de Cebu. Ateneo de Manila UP, 2011.

Brown, S. \& Firefly 36o. “The Annual Feast of the Black Nazarene." CNNiReport, 9 Jan. 2013, ireport.cnn.com/docs/DOC-907647.

Bulatao, Jaime. Split-level Christianity. Ateneo de Manila UP, 1966.

Calano, Mark Joseph. "The Black Nazarene, Quiapo, and the Weak Philippine State." Kritika Kultura, no. 25, 2015, pp. 166-187.

Cornelio, Jayeel S. "Popular Religion and the Turn to Everyday Authenticity: Reflections On the Contemporary Study of Philippine Catholicism." Philippine Studies: Historical and Ethnographic Viewpoints, vol. 62, nos. 3-4, 2014, pp. 471-50o.

De La Paz, Cecilia. "The Potency of Poón: Religious Sculpture, Performativity, and the Mahal na Senyor of Lucban." Spirit of Things, pp. 183-196.

De Mesa, Jose, and Lode Wostyn. Doing Christology: The Re-appropriation of a Tradition. Claretian Publications, 1989.

--. Doing Theology: Basic Realities and Processes. Claretian, 1990.

Derrida, Jacques, and Maurizio Ferarris. A Taste for the Secret. Translated by Giacomo Donis, Blackwell Publishers, 2001.

Doyo, Ma. Ceres P. “The Nazarene's Nightmare.” Philippine Daily Inquirer. 9 Jan. 2013, opinion.inquirer.net/44529/the-nazarenes-nightmare.

Eliade, Mircea. The Sacred and the Profane: The Nature of Religion: The Significance of Religious Myth, Symbolism, and Ritual Within Life and Culture. Harper, 1959.

Genova, Windsor. “Thousands of 'Black Jesus' Devotees Join Manila Procession Amid Bomb Threat," International Business Times. 10 Jan. 2012, www.ibtimes.com.au/ thousands-black-jesus-devotees-join-manila-procession-amid-bomb-threat-1292219.

Giddens, Anthony. The Consequences of Modernity. Stanford UP, 1990.

-.. Modernity and Self-identity: Self and Society in the Late Modern Age. Stanford UP, 1991.

Guidaben, Agatha. "March of the Multitudes: Nazarene Procession Grows Every Year." GMA News Online, 9 Jan. 2014, www.gmanetwork.com/news/story/343106/news/ nation/march-of-the-multitudes-nazarene-procession-grows-every-year. 
Hegina, Aries Joseph, and Bong Lozada. "2 Dead, 2 Hurt By Electric Shock in 19hour Black Nazarene 'Traslacion.”' INQUIRER.net, 10 Jan. 2015, newsinfo.inquirer. net/66367I/I-dead-2-electrocuted-in-I9-hour-black-nazarene-traslacion.

Hervieu-Leger, Danièle. "Space and Religion: New Approaches to Religious Spatiality in Modernity." International Journal of Urban and Regional Research, vol. 26, no. 1, 2002, pp. 99-105.

Ileto, Reynaldo. Pasyon and Revolution: Popular Movements in the Philippines, 1840-1910. Ateneo de Manila UP, 1979.

Jimenes-David, Rina. "Batya't Palu-palo' Christianity." Philippine Daily Inquirer, 9 Jan. 2012, opinion.inquirer.net/20827/'batya 't-palu-palo'-christianity.

Jocano, Felipe Landa. Slum as a Way of Life: A Study of Coping Behavior in an Urban Environment. U of the Philippines P, 1975.

--. Folk Christianity: A Preliminary Study of Conversion and Patterning of Christian Experience in the Philippines. Trinity Research Institute, 1981.

Levi-Strauss, Claude. The Savage Mind. Wedenfeld and Nicholson, 1966.

Macdonald, Charles. "Folk Catholicism and Pre-Spanish Religion in the Philippines." Philippine Studies, vol. 52, no. 1, 2004, pp. 78-93.

Matienzo, Rhochie Avelino E. "The Quiapo Leap: A Philosophical Reading of the Religious Experience of the Black Nazarene Popular Devotion." UST Inaugural Lectures, 19 Apr. 2015. Published in Kritike, vol. 10, no. 4, December 2016, pp. 29-43.

McGuire, Meredith. Lived Religion: Faith and Practice in Everyday Life. Oxford UP, 2008.

Mercado, Leonardo. Elements of Filipino Philosophy. Divine Word UP, 1974.

Miranda, Dionisio. Pagkamakatao: Reflections on the Theological Virtues in the Philippine Context. Logos, 1987.

Mojares, Resil. 2002. "Stalking the Virgin: The Genealogy of the Cebuano Virgin of Guadalupe." Philippine Quarterly of Culture and Society, vol. 30, 2002, pp. 138-171.

Murphy, Peter, and Trevor Hogan. "Discordant Order: Manila's Neo-patrimonial Urbanism." Thesis Eleven, vol. 112, issue 1, 2012, pp. 10-34.

Pace, Enzo. "New Paradigms in the Study of Popular Religion." Archives des Sciences Sociales des Religions, vol. 64, July-Sep., pp. 7-14.

Pagulong, Charmie Joy. “Timeline: Deaths, Injuries During Quiapo Procession.” The Philippine Star, 8 Jan. 2014, www.philstar.com/headlines/765471/ timeline-deaths-injuries-during-quiapo-procession.

Parker, Cristian. Popular Religion and Modernization in Latin America: A Different Logic. Orbis, 1996.

Phan, Peter. "Popular Religion, the Liturgy, and the Cult of the Dead." East Asian Pastoral Review, vol. 42, 2005, pp. 1-2. www.eapi.org.ph/resources/ eapr/east-asian-pastoral-review-2005/volume-42-2005-number-1-2/ popular-religion-the-liturgy-and-the-cult-of-the-dead/.

Philippines News Agency “2014 'Traslacion' of the Black Nazarene Takes Almost 19 Hours," INTERAKSYON.com, 10 Jan. 2014, www.interaksyon.com/ article/78428/20I4-traslacion-of-the-black-nazarene-takes-almost-I9-hours. 
Rodriguez, Agustin Martin. Governing the Other: Exploring the Discourse of Democracy in a Multiverse of Reason. Ateneo de Manila UP, 2009.

Sapitula, Manuel Victor. "Marian Piety and Modernity: The Perpetual Help Devotion as Popular Religion in the Philippines." Philippine Studies: Historical and Ethnographic Viewpoints, vol. 62, nos. 3-4, 2014, pp. 399-424.

Taylor, Charles. The Ethics of Authenticity. Harvard UP, 1992.

--. Sources of the Self: The Making of the Modern Identity. Harvard UP, 1989.

Tremlett, Paul-Francois. "Power, Invulnerability, Beauty: Producing and Transforming Male Bodies in the Lowland Christianised Philippines." Occasional Papers in Gender Theory and the Study of Religions, no. 1, School of Oriental and African Studies' Centre for Gender and Religion Research, 2006. www.soas.ac.uk/grr/publications/ le2458o.pdf.

Trinidad, Recah. "Nazarene Devotion: Portrait of a Nation." Philippine Daily Inquirer, 8 Jan. 2012, newsinfo.inquirer.net/I24I69/nazarene-devotion-portrait-of-a-nation.

Turner, Victor, and Edith Turner. Image and Pilgrimage in Christian Culture: Anthropological Perspectives. Columbia UP, 1978.

Uy, Jocelyn. "Black Nazarene Devotees Displayed 'Excess Fanaticism.' Says Quiapo Priest." Inquirer.net, 11 Jan. 2012, newsinfo.inquirer.net/I25993/ black-nazarene-devotees-displayed-'excess-fanaticism'-says-quiapo-priest.

Zialcita, Fernando. "Popular Interpretations of the Passion of Christ." Philippine Sociological Review vol. 34, nos. 1-4, 1986, pp. 56-62. 